\title{
The Carnegie Trusts
}

$\mathrm{A}^{\mathrm{N}}$ NDREW CARNEGIE was born on November 25,1835 , the son of a hand-loom weaver of Dunfermline. A centenary commemorative volume bears the title "Andrew Carnegie: the Trusts and their Work".* There is a peculiar fitness in the close association of his name with the word 'trust', for the notion of trust was fundamental in the creed which dictated his disposition of the vast wealth he controlled. He believed that great private wealth was a public trust; that the increment of large fortunes was socially created and should be redispensed to the society that had created it. In conformity with this "gospel of wealth", as he called it, nine-tenths of his public benefactions were designed to promote the welfare of the people of the United States of America, the country of his adoption (he emigrated to America with his parents in 1848), and the earliest of the series of great foundations which have immortalised his name and ideals was for the creation of a cultural centre in Pittsburgh, the city where he had laid the foundations of his career and his fortune.

The series culminated in 1911, when he had already given away 300 million dollars, in the endowment with 125 million dollars of the Carnegie Corporation of New York. The field of activity of this corporation, limited at first to the United States, has been extended by an amendment of its charter to the British Dominions and Colonies. Lastly, in 1914, came the United Kingdom Trust, for assisting pioneer projects of national scope. Thus the whole series dates from the twenty years immediately preceding the Great War, comprising the span of life between Mr. Carnegie's sixtieth and eightieth birthdays. He died on August 11, 1919. A brief summary of the American foundations, including, in addition to those already mentioned, the Carnegie Institution of Washington, the Carnegie Foundation for the Advancement of Teaching, and the Carnegie Endowment for International Peace, is given in the present volume, the greater part of which is devoted to the history of the British Trusts, namely, that for the Universities of Scotland (1901), the Dunfermline (1903), the Hero Fund Trust of Great Britain (1908), and the United Kingdom Trust.

Carnegie's gifts, says Mr. Ramsay MacDonald in a foreword, were never casual, but bore the stamp of the constructive genius which displayed itself in everything he did. Of the unifying purpose underIying his benefactions in the United States it has been said: "not succour nor alleviation, but opportunity for growth . . . his mind was on the underprivileged : not the materially under-privileged, that they might increase their substance, so much as the under-privileged in access to means of cultural eleva. tion; and the under-privileged not as individuals, but as members of a society. In opportunity for cultural advancement of the whole, he saw the betterment for which all men strove". These same principles are well exemplified in his scheme for the universities of Scotland : one half of the revenue of his Trust to be used to pay the fees of deserving poor

* Centenary of the Birth of Andrew Carnegie. The British Trusts and their Work, with a Chapter on the American Foundations. Pp. $\mathrm{x}+155+29$ plates. (Dunfermiline: The Carnegie United Kingdom Trust, Comely Park House, 1935.) students and the other half to improve the universities. Nor was he unmindful of the vital importance for the improvement of universities of encouraging scientific research. He was deeply impressed by the friendly advice on this point of Mr. A. J. Balfour (afterwards the Earl of Balfour), and took a particular interest in the Trust's provision for discovering and, so far as possible, supplying the demands for higher study and research throughout Scotland.

Carnegie's religion was manifestly a living force; but the flame of his philanthropy burned with a light neither dimmed nor refracted by any cloud of dogma, and he displayed in relation to his Trusts something of the humility and the detachment of the scientific investigator. The scope of the Dunfermline is, of course, purely local, while that of the United Kingdom Trust is national, but they are alike in leaving to the Trustees a freedom from restrictive definition that is rare in the history of charitable trusts. In an explanatory letter to the Dunfermline Trustees, Mr. Carnegie emphasised the experimental character of the work he was entrusting to them : "The problem you have to solve is "What can be done in towns for the benefit of the masses by money in the hands of the most public-spirited citizens'. If you prove that good can be done you open new fields to the rich which I am certain they are to be more and more anxious to find for their surplus wealth. Remember you are pioneers, and do not be afraid of making mistakes. . . . I can imagine it may be your duty in the future to abandon beneficent fields from time to time when municipalities enlarge their spheres of action and embrace these. ... As con. ditions of life change rapidly you will not be restricted as to your plans or the scope of your activities". At the same time he left no room for doubt as to what he meant by "benefit". He confided to them his aspiration that the Trust would be the means of bringing "into the monotonous lives of the toiling masses of Dunfermline more of sweetness and light", of giving to them-- "especially the young-some charm, some happiness, some elevating conditions of life which residence elsewhere would have denied".

The United Kingdom Trust is, in respect of the wide effects of its many-sided activities, the most interesting of Mr. Carnegie 's ventures. Here the 'pioneer' function of the Trust supplies its keynote, and the Trustees are enjoined to bear in mind that the needs of the community are continually changing "as the masses advance". A very large proportion of their income is expended on large-scale experiments planned over a limited period of years, and applications for grants are invited under specified conditions and upon a more or less rigidly fixed scale. Public opinion is thus created and consolidated in favour of the particular services in view, as, for example, county and regional libraries, maternity and child welfare, playing fields and play centres for young children and village halls.

A striking success was achieved by the Trustees' playing field policy, begun in 1927 with an allocation of $£ 200,000$ in response to an appeal by H.M. the King, and carried out in collaboration with the National Playing Fields Association to such purpose that the country is richer by playing fields to the value of 
nearly $£ 2,000,000$, and more than 6,000 acres of land has been preserved for all time for recreation. In this as in other enterprises the Trustees have hastened that enlargement of the spheres of action of local authorities foreseen by Mr. Carnegie. As they point out in the review contributed by them to "The Trusts and their Work", there has been since the Great War a growing recognition by local authorities that certain activities of a pioneer kind are more effectively administered by volunteer workers than by the official machine. This has led to enlightened experiments in which the Trustees have participated and have assisted voluntary bodies to earn Government grants.

Of post-War developments in the social life of the people of the United Kingdom there is one that would, beyond all others, had he lived to see it, have excited Mr. Carnegie's interest and aroused in him, as an apostle of sweetness and light, the gravest concern-the gigantic growth of the cinematograph industry. The inquiry by the Commission on Edueational and Cultural Films and the resulting report entitled "The Film in Education", which led to the establishment in 1933 of the British Film Institute, were financed by the Trustees to the extent of $£ 6,100$. In the face of their splendid record of work accomplished, it would be hypercritical to suggest that the Trustees might have hastened the advent of that Institute, but one cannot help wishing that it had come into existence ten years earlier.

At the dawn of the twentieth century, Mr. Carnegie was already sixty-five years of age, and many of his views on social problems were, of course, coloured by a social background as far removed from ours of to-day as was that from the Middle Ages. But these few notes on "The Trusts and their Work" are sufficient to show that he is very far indeed from being a spent or retro-active force.

\section{Resolutions of the Sixth International Botanical Congress}

$\mathrm{T}$ HE Executive Committee of the Sixth International Botanical Congress recently held at Amsterdam (see Nature of November 12) has issued the draft of the general and sectional resolutions passed at the final plenary meeting.

It was agreed that the Botanical Section of the International Union of Biological Sciences should act as an administrative link between successive International Botanical Congresses, and should be authorised to carry through the resolutions passed. The Union was asked to approach the various Governments in order to obtain inexpensive facilities for the exchange by post or otherwise of collections of dried plants.

The attention of public and scientific bodies was directed to the danger of destruction of natural vegetation in tropical and subtropical countries by brushwood and prairie fires and by human agency. The necessity of permanent natural reserves, and of the maintenance of an adequate proportion of natural forest areas was emphasised, and a committee was set up to study associated problems and to inform the Governments concerned. The importance of international discussions and action in the campaign against plant diseases and insect pests was stressedthis resolution is to be brought to the attention of the League of Nations.
A committee was appointed to olaborate proposals for a classification of climates from a phytogeographic point of view ; the committee on the description and nomenclature of plant viruses was ompowerod to continue its work; and application is to be made to the International Committee for Genetical Congresses for the appointment of a committee to clarify and improve the terminology of geneties and cytology. Propositions in favour of the proparation. of a new "Phytography"- - a compilation of lists of the collections represented in the larger herbaria-and of an "International Dictionary of Botanical Terminology", were approved; also the desirability of photographing the Linnæan type specimens at the Linnean Society and the British Museum.

Appreciation of the admirable work of the Centraalbureau voor Sehimmelcultures at Baarn was expressed, and also grave concern at the present financial difficulties of what is essentially an international institution. The editorial committee of the International Rules of Botanical Nomonclature, third ed. (1935) was thanked for its work; the decisions of the Section of Taxonomy and Nomenclature concerning modifications of the rules were accepted, and the appointment of the standing committees of the Section was sanctioned.

\section{Progressive Traffic Signals in London}

$I^{\mathrm{N}}$ the engineering supplement to the Siemens Magazine for November, Mr. F. G. Tyack gives a full account of the 'Autoflex progressive system' of traffic control which the experience of the last two years has shown to be very satisfactory in certain London streets. The problem is a difficult one, but its analogy to the corresponding problem of controlling 'the traffic' in telephony has been a great help in finding a solution. For the first time the theory of probability has been applied to street traffic problems. Mathematicians will be interested to learn that the method of 'least squares' is applied to the plotting of time and distance diagrams.
Motorists are well aware that one of the principal difficulties experienced by traffic police at complex intersections, or along busy thoroughfares, is efficient co-operation. They are often not in sight of one another and are generally fully occupied with the control of traffic in their immediate vicinity. Electrical signalling has been found to be the most convenient means of controlling the traffic.

In the flexible progressive system, there is a large number of 'local' traffic controlling devices at each intersection throughout the controlled area. These are linked electrically to a master controller which co-ordinates the indications given to the traffic and 